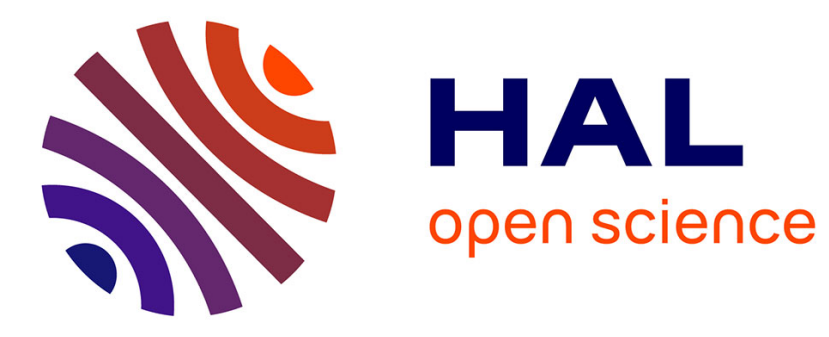

\title{
Ensuring Child Rights for a Just Society
}

\author{
Umar Abdullahi Ahmed, Most. Asikha Aktar, Md. Mahmudul Alam
}

\section{To cite this version:}

Umar Abdullahi Ahmed, Most. Asikha Aktar, Md. Mahmudul Alam. Ensuring Child Rights for a Just Society. Walter Leal Filho; Anabela Marisa Azul; Luciana Brandli; Amanda Lange Salvia; Pinar Gökcin Özuyar; Tony Wall. Peace, Justice and Strong Institutions, Springer International Publishing, pp.1-12, 2021, Encyclopedia of the UN Sustainable Development Goals, 978-3-319-710662. 10.1007/978-3-319-71066-2_146-1. hal-03520066

\section{HAL Id: hal-03520066 https://hal.science/hal-03520066}

Submitted on 10 Jan 2022

HAL is a multi-disciplinary open access archive for the deposit and dissemination of scientific research documents, whether they are published or not. The documents may come from teaching and research institutions in France or abroad, or from public or private research centers.
L'archive ouverte pluridisciplinaire HAL, est destinée au dépôt et à la diffusion de documents scientifiques de niveau recherche, publiés ou non, émanant des établissements d'enseignement et de recherche français ou étrangers, des laboratoires publics ou privés. 


\title{
Ensuring Child Rights for a Just Society
}

\author{
Umar Abdullahi Ahmed * \\ Department of Economics \\ Kaduna State University \\ Kaduna-Nigeria \\ Email: umed313@yahoo.com \\ Most. Asikha Aktar \\ Department of Economics \\ Comilla University \\ Cumilla, Bangladesh \\ Email: asikharita@gmail.com \\ Md. Mahmudul Alam \\ School of Economics, Finance and Banking \\ Universiti Utara Malaysia \\ Sintok, Kedah, Malaysia. \\ Email: rony000@gmail.com \\ * Corresponding Author
}

\section{Citation Reference:}

Ahmed, U.A., Aktar M.A., \& Alam M.M. (2020). Ensuring Child Rights for a Just Society. In: Walter Leal Filho et al. (eds), Peace, Justice, and Strong Institution: Encyclopedia of the UN Sustainable Development Goals. Springer, Cham. ISBN: 978-3-319-71066-2. (online) https://doi.org/10.1007/978-3-319-71066-2_146-1

This is a pre-publication copy.

The published article is copyrighted by the publisher. 


\section{Ensuring Child Rights for a Just Society}

\section{Definition}

As clearly defined by the United Nations Convention on the Rights of the Child (UNCRC), children's rights entails a conceptual method and guide towards recognising the children as the rightful holders of universally accepted rights just like other human beings (UNCRC, 1989). It is generally established that children are entitled to fundamental universally-accepted human rights that include the right to a decent life, equality, and human dignity. Furthermore, children are also entitled to certain "child-specific rights" which comprise of the right to proper development, livelihood and attention, and right to education. The children's rights form a division of human rights that gives special attention to exceptional care and protection rights, mainly to children or minors. In essence, human rights are those moral values or norms that define specific and basic standards of human and social behaviours, which are regular protection within domestic and universal laws (Campbell 1992).

A just society refers to any community that can share and distribute those vital things we have value and reward for (Sandel, 2009). Such may include income and wealth, influence and opportunities, rights and responsibilities, offices, and honours; that correctly, gives each individual his or her right. In this regard, what individuals get in the distribution process of available goods and services can be determined based on welfare maximisation principles, respect for individual freedoms, and upholding human virtues. It is an essential aspect that raised global commitment since its acceptance within the UN Sustainable Development Agenda 2030 framework (Lee et al., 2016). Subsequently, the simple expression of ensuring equal access to justice for all becomes relevant, thereby making all concerned parties remain actively involved in fulfilling it.

\section{Introduction}

The definition and understanding of children's rights remain critical, especially within the framework and provisions of the government's strategies and actions at local, national, and international levels. In general terms, the United Nations Convention on the Rights of the Child (UNCRC, 1989) serves as a legal framework towards ensuring that the child's rights remain indisputably and highly-embraced resolution of the United Nations. Such a framework came into force more swiftly than any other earlier human rights accord (Detrick, 1999). In this regard, a child refers to any human being who falls below eighteen years except under specific national legal provisions that classify such persons as grown-ups earlier than the age of 18 (United Nations 1989). Hence, the UNCRC gives children more protection in terms of their legal human rights through its ratification by virtually all member countries belonging to the United Nations. This makes children have minds of theirs enable them to agree and as well disagree where necessary. In this regard, adults should be prepared to allow children to decide on things that matter to them. Afterwards, children are not dummies in possession of adults; they also need liberty. Likewise, to enjoy a smooth level of physical growth and development, a truly social, genuine, intellectual, and psychological opportunity should be made accessible to them easily (Geeta, 2015). The environment must be supportive and motivating. Children are youthful, reliant, and need attention towards their welfare and development.

Regardless of the inspiring development recorded in recent decades, many children are living without their fundamental rights. Presently as more than before, children's lives are continuously affected by violence, war, and the effects of other environmental changes 
(Shenoda et al. 2018). The global estimate shows that around 800 million children live in fragile-prone and war-affected places where children's rights face frequent deprivation, and childhood gets lost fiercely through misuse, maltreatment, and slavery (UN, 2018). While there are continuing deliberations regarding the protection of children's rights, the need to include deprived children and ensure justice for all categories of children may continue to be necessary, especially from a planning and policy perspective that needs better cognisance (Miles and Singal (2010). Such strategies must provide the required attention and necessary modifications with adaptable measures to address the child's various challenges. It is crucial to put more efforts at national and international levels towards providing the required resources to support a child's rights. More are urgently in need to achieve the desired result. More importantly, this can be strategically put in place at various geographical levels and other economic and socioeconomic spaces.

Attaining peaceful and just societies for all remains a central point of the 2030 roadmap on Sustainable Development. Hence, establishing robust, functional, transparent, and all-inclusive institutions will go a long way towards promoting sustainable development. In this manner, goal 16 of SDG that provides for "promoting peaceful and all-inclusive societies for sustainable development, providing access to justice for all, and building effective, accountable, and inclusive institutions on all levels" remains an essential catalyst for the achievement of a complete SDGs. Therefore, it is crucial to engage all stakeholders -local and internationallyto attain better situations. Following the introduction, this entry presents the various ways of child rights violations and the consequences of such violations. Furthermore, the framework for child rights protection, especially in developing countries, and the inclusion of deprived children and justice for all children were also highlighted. The policy recommendations form the concluding part of this entry

\section{Ways of violating child rights}

The rights of children cover the life cycle between the ages of zero and eighteen. Since children easily fall victim to power-abuse by their teachers, parents, and governments, they need adequate shield through a specific convention in international law Hillis et al. (2016). Due to young people's vulnerability, specific human rights standards for children are essential in most cases. Experience has shown that teachers and parents frequently do not have children's best interests in their attention and emotions. For example, children's rights include rights for health, freedom of speech, engaging in all matters directly affecting their well-being, or their right to be shielded from any sort of discrimination or violence. The word "Violation of the rights of children" therefore applies to any violation of the rights of children that needs protection, and the most basic ways of violating the rights of children are as follows:

\section{(i) Child labour}

According to ILO (2017), child labour can be seen as any work that denies children their legitimate childhood, potentialities, and personal dignity, negatively affecting their physical and mental growth capacity. Furthermore, any type of work that undermines the children's moral upbringing, cognitive ability, physical and social exposure can be seen as child labour. It may also obstruct their schooling activities, deprive them of the right and opportunity to join proper schooling or force them to combine education with exceptionally long and intense work. Accordingly, child labour results in severe violations of the fundamental aspect of human rights, which has been revealed to impede children's development and developmental process, eventually resulting in lifelong physical or psychosomatic damage. Furthermore, evidence shows a strong connection between household poverty and the level of child labour. 
Thus, child labour spreads high poverty among generations by denying the children of those poor households access to schooling and restraining their prospects for a possible rise in social status. Similarly, it subjects the emotional and physical health of children at risk and their education as well. Various circumstances of child labour abuse operating in unsafe environments can be included. Agricultural activities and places; where dangerous chemicals and hazardous equipment are used, the manufacturing industry, or domestic child labour are some examples. All of them pose severe challenges to children's physical and psychological integrity. According to Senante et al. (2018), approximately 126 million children between the ages of 5-17 work under unsafe conditions, and 2000 children die annually at work. At the same time, the number of children who are sick or are injured due to the risky jobs they do is unidentified. In addition to suffering from the violation of their most fundamental rights, these children and adolescents find themselves vulnerable to abuses and trafficking conditions. They also find themselves as criminals of a debt contracted by their families on several occasions. It is estimated that due to family debts, 5 to 7 million children are aware of forced and bonded laboratories (Senante et al. 2018).

\section{(ii) Child trafficking}

A child has the potential to be a victim of trafficking. The trafficking of children resembles slavery; the victims are robbed of their rights. The child is manipulated and kept under unduecontrol through blackmail and threats and has no access to basic education. Trafficking in children refers to sexual exploitation, exploitation of labour, and organ removal. Children are compelled to pursue prostitution and even to marry in the event of sexual abuse. They are also documented in cases of sexual assault that will be marketed as pornography later on. Approximately 1.8 million children are believed to be coerced into prostitution and pornography, of which 1.2 million are victims of trafficking in children (Senante et al. 2018). Every year, one million children enter the industry of pornography and prostitution (UN 2006). The various types of child trafficking constitute one of the most severe abuses of human rights, and more precisely, of the child's rights, which are recognised and enlisted in the Convention on the Rights of the Child. Owing to the psychological effects of the trafficking of children, victims frequently refuse to reintegrate into society.

\section{(iii) Domestic Violence}

Violence at home is a reasonably common occurrence all over the world but not always apparent (Ertan et al., 2020). Usually, the violence at home is carried out by someone who lives and interacts with the child directly. This person is in charge of the care and safety of the infant. The child is expected to trust this person and feel affection. However, the two main forms of violence are most commonly combined: physical violence, including sexual assault, and emotional violence, including embarrassment, threats, insults, abandonment, rejection, and exclusion or separation from the family sphere. Some forms of abuse, such as those associated with traditional and cultural practices (witchcraft, early and forced marriage, feminine genital mutilation) or when children have grown up in the sense of gender violence, are unique to the family circle. From 133 to 275 million children are victims of domestic violence worldwide every year (UN 2006).

\section{(iv) Gender Discrimination}

In situations of suffering the violation of their most fundamental rights, girls' vulnerable status is far greater than that faced by boys. Their feminine condition makes them more fragile; the different forms of aggression are more exposed to them. Early marriage is a major issue that is commonly recognised as a violation of children's rights under the age of 18; it is a direct 
discrimination form against girls who are often deprived of their fundamental rights to education, health, and social advancement and justice. Approximately 650 million girls and women who are currently alive got married out as children under the age of 18 (UN 2020). While some of these marriages are not by force, they are mostly the fruit of a deal between the girl's parents and the fiancé, who is older in general. In effect, most girls who get married never return to school; they engage in domestic labour. Girls are often exposed to early pregnancies, which undermines their well-being and the baby's (there is a relation between infant/maternal mortality and early marriage). They are also exposed to fistulas, sexually transmitted diseases, and many other health conditions.

Another type of violence, female genital mutilation (FGM), often victimises girls. More than 100 and 140 million girls and women are estimated to have experienced genital mutilation worldwide (Senante et al., 2018). It violates the girls' fundamental rights, in addition to being a patriarchal practice, such as her right to health, the right to freedom to determine the dignity of her own body, and the right to be protected by violent actions, etc. Girls between the ages of 4-14 (and disturbingly, some cases have been identified in babies) are most frequently the victims. In matters related to rape, girls are more vulnerable victims with severe health effects (AIDS transmission or early pregnancy) and emotional consequences (such as psychological distress).

\section{(v) Armed Conflicts}

The majority of victims of armed conflicts are children (Sever and Balat, 2020). Living in the context of war means a dangerous situation for children. In this case, children are uprooted and sometimes totally isolated from their families, exposing them even further to all forms of crime, such as child trafficking, rape, and kidnapping.

All the ways of abusing the rights of children can be legitimately defined as harmful activities, but the common feature of the ones outlined in this entry is that they are focused on custom, culture, faith, or superstition and are perpetrated and actively condoned within the society of the child by the parents or majority of adults. All are an assault on the child's fundamental dignity and breach widely accepted international human rights principles.

\section{Socio-Economic Consequences of Violating the Child Rights}

Violating children's rights has a lifelong effect on the well-being and health of children, communities, families, and nations. The horrible abuse of children has been internationally recognised as a matter of concern with significant adverse social consequences (Debowska et al., 2018). Such consequences include temporary injuries, mortality, weaken the development of the brain and nervous, negative coping and health risk behaviours, unintentional pregnancies, a wide range of non-communicable diseases, and prospects for the next generations to affect. For instance, girls who bear children are five times more likely to die in childbirth when they are 10-14 years of age than those aged 20 or over, while those between 15-19 years are twice likely to die (Temin and Levine 2010). Similarly, teen mothers' babies are twice likely to die before the age of one, unlike those of mothers in their twenties (ICRW 2007). Such a situation results in the death of millions of young mothers' babies worldwide each year because of causes related to pregnancy and childbirth. The risk of accidents is high for children who are left unattended or supervised by pre-teen siblings.

Studies performed in OECD countries show that children exposed to childhood violence have higher rates than children not exposed to violence due to depression, obesity, smoking, 
unintentional pregnancy, high-risk sexual activity, and drug and alcohol use. In turn, this can contribute to some of the major causes of death, sickness, and disability, such as sexually transmitted diseases ( STDs), heart disease, suicide, and cancer (WHO and ISPCAN 2006). The estimates of WHO cited in Pinheiro (2006 ) suggest that childhood sexual violence can be linked to $4 \%$ and $8 \%$ of the global liability of depression, anxiety, and alcohol abuse, $7 \%$ and $11 \%$ of attempts to suicide, and $21 \%$ and $33 \%$ of the global liability of post-traumatic stress disorder (all statistics for females and males, respectively). People who have experienced childhood sexual or physical abuse are often more likely to witness and perpetrate violence in adulthood (UNICEF, 2020b).

It is clear that numerous violence against the child knows no limits in terms of cultural dimension, class, educational status, income level or ethnic affiliation. It occurs in institutions provided for their upbringing and protection within homes, schools, and online. It has been shown that globally, around one billion children are experiencing one form of emotionallyrelated, physical or sexually-inclined violence on an annual basis (Hillis et al., 2017). Such a situation results in the death of at least one child in around five minutes. Despite the endemic proportions, such horrible violence against the child frequently remains concealed and socially ignored.

Although most of the studies have been conducted in OECD countries, there is increasing (primarily qualitative) warning from middle and low-income countries about the medium to long-term effects of various child protection rights abuses. Experiencing both sexual and physical abuse is correlated with decreased academic achievement and earlier dropout in academics, as the correlated anxiety, fear, and depression affect children's ability to focus and impair their interest in studies (Deb and Modak 2010; Plan International 2006; USAID 2003). Altogether, these impacts on physical and mental well-being and education are likely related to a higher possibility of rising poverty. Children who have grown up in societies are often less prepared to integrate and find work in the broader society and thus are induced by a higher risk of poverty (UNICEF, 2010). The violation of children's rights considerably weakens the economic development of nations and communities, in addition to the instant and long-term costs to society (Quennerstedt et al. 2018). The financial costs accompanying child abuse and neglect, including the potential loss of income and mental health care, were measured at US\$ 94 billion in the United States in 2001 (Fromm 2001). For immediate health and legal services alone, an estimated expense of US\$ 1.2 billion has been cited in the UK (National Commission report 1996). And it is projected that the global economic costs arising from psychological, physical, and sexual abuse against children are as high as $\$ 7$ trillion-approximately $8 \%$ of global GDP annually (UNICEF 2020a). These expenses are paid for by increased public spending on special education, child care, and medical and psychological treatment for victims. For example, victims struggling with the physical and psycho-social consequences of abuse often face obstacles involving public life and accomplishing their prospective. Furthermore, violence, especially in schools, undermines children's capacity to learn, with effects that can pass through generations on their education and job opportunities.

\section{Existing legal framework for protecting child rights, especially in developing countries}

The protection and promotion of children's rights is a fundamental task guaranteed by the Convention on the Rights of the Child (CRC). Violence towards children exists in all parts of the world and all aspects of their lives, including at home, at work, school, and more generally in the community. For millions of children in developing countries, violence is common, systematic, and, with long-lasting effects, remains a harsh reality in their lives. Guaranteeing 
child rights not only contributes to the well-being and welfare of each child but also to the country's overall economic and social development. There is no question that law is a tool to ensure all government policy and planning's smooth operation. For instance, in most developing countries, it is a government policy that no child is exploited or overlooked. Therefore, the majority of developing countries have enacted laws protecting the rights of children. For example, Table 1 depicts the number of regulations adopted by developing countries to protect child rights.

Table 1: Legal framework for protection and promotion of the children rights, by country

\begin{tabular}{|c|c|}
\hline Countries & Legal Framework \\
\hline Afghanistan & Juvenile Code, 2005; Law on Protection of Child Rights \\
\hline Bangladesh & Children Act, 2013 \\
\hline Bhutan & Child Care and Protection Act, 2011 \\
\hline India & Juvenile Justice (Care and Protection of Children) Act, 2015 \\
\hline Maldives & Child Rights Protection Act (No.19/2019) \\
\hline Nepal & Act Relating to Children, 2018 \\
\hline $\begin{array}{l}\text { Pakistan (by province): } \\
\text { - } \text { Balochistan } \\
\text { - } \text { Gilgit-Baltistan } \\
\text { - } \text { Islamabad Capital } \\
\text { Territory (ICT) } \\
\text { - } \text { Khyber } \\
\text { - Pakhtunkhwa } \\
\text { - Punjab } \\
\text { - Sindh } \\
\end{array}$ & $\begin{array}{l}\text { - Balochistan Child Protection Act, } 2016 \\
\text { - Gilgit-Baltistan Child Protection Response Act, } 2017 \\
\text { - Islamabad Capital Territory Child Protection Act, } 2018 \\
\text { - Khyber Pakhtunkhwa Child Protection and Welfare Act, } \\
2010 \\
\text { - Punjab Destitute and Neglected Children Act, 2004 } \\
\text { - Sindh Child Protection Authority Act, 2011; Sindh } \\
\text { Children Act, } 1955\end{array}$ \\
\hline Sri Lanka & $\begin{array}{l}\text { Children and Young Persons Ordinance; National Child } \\
\text { Protection Authority Act }\end{array}$ \\
\hline Malaysia & The Child Act 2001; The Child Witness Act, 2007 \\
\hline Nigeria & The Child Act, 2003 \\
\hline
\end{tabular}

Source: UNICEF 2020b

All the countries other than Bangladesh, as indicated in Table 1, have a general declaration of the government's duty to protect children from all forms of crime, harassment, neglect, and exploitation. They are also to provide necessary assistance to children in need of protection, generally in compliance with national constitutional and child protection legislation. This is framed explicitly in Bhutan and Maldives as a government responsibility to support families in their child-rearing duties. Bhutan also requires the government to provide opportunities for families to learn about parenting roles and responsibilities and promote positive relationships between parents and children. Most countries already have a certain legal structure that defines the government's duty to provide children and families with child protection services. It is a provincial/territorial duty in Pakistan to provide child protection services as guided by subnational legislation.

\section{Inclusion of deprived children and ensuring justice for all children}

It has been clear that not all children are sufficiently fortunate to have access to a conducive atmosphere which provides suitable developmental prospects. The necessity to ensure some children's protection more than others remains certain, precisely because of their socio-political and economic" conditions alongside the geographical placement. Such children tend to be more 
vulnerable regarding the risks and hazards to their fundamental rights towards existence, development, protection, and possible involvement. This refers to the deprived children who are mainly under challenging conditions. In this, the deprived children, also known as "children in particularly troublesome conditions" (CEDC), remain global problems. They experience a lot from deprivation, neglect, and abuse for no flaw of theirs and for specific reasons well beyond their ability to control. It remains a tremendously social burden worldwide that has drawn in the whole global community's great attention, right from professionals within the different pediatrics, social-work, administrators, legislators, psychologists, and psychiatry sections.

The CEDC are those children whose fundamental needs of life are not provided for. Children in challenging conditions symbolise vast and diverse individuals. Some types of social disturbance are common in their way of life. These children have exceptional needs, exclusively the pressing need for psycho-social support required. The requirements differ significantly, particularly as the conditions and reasons behind such challenges in existence differ and are also continuously evolving. A portion of these children lives with their families, while some don't or could even be orphans.

Similarly, some may be working or just roaming the streets, while others may be in unavoidable conflict with instituted authorities or influenced by natural catastrophes or armed conflicts. Children could be sexually abused, pushed, and forced into work slavery, which may subsequently detach them from the pleasures and virtues of childhood or even trafficked. The health situation and well-being of CEDC are seriously undermined. It could depend on the social arbitrations, moral integrity, and sensitivity of "social society" and provisions by laws within the system and the idea of rehabilitative administrations towards restoring their childhood to them. Possible results rely upon the power and span of the misfortune, gender, and the children's age and the availability of possible support help and protective mechanisms. Based on the current social situations, especially over the recent years, economic participation, family conditions, and general situations of living, deprived children have also been classified as those in difficult circumstances, which include the following.

\section{Homeless Children}

The term "homeless children" entails those children who have no fixed, consistent, and adequate nighttime habitation. This may include those children who happen to be sharing the available housing accommodation of others due to a loss of housing, prevailing economic hardship, or other related reasons. They may as well be living in places such as motels, trailer parks, or other camping grounds because of the lack of better alternative accommodations. Migration in anticipation of better livelihood and yarning towards better life remains a major root cause of homelessness. The issue is more pronounced in urban areas. The rising rate of globalization has also contributed to destabilising rural livelihoods' standards, contributing to this aspect.

\section{Migrant Children}

The rising rate of migration by families, especially from rural to urban areas, has caused a severe overcrowding rate, humiliating working conditions, homelessness, high deprivation of required necessities of life, and terrible living conditions, particularly in the city. Nevertheless, returning to places of origin, especially villages, can result in high starvation; thus, remaining within the town may physically allow for possible survival. Such an influx from rural to urban 
areas has contributed to creating accommodation problems, hygiene, and other sanitation challenges leading to hostility and marginalisation. In all, while parents are busy trying to make "ends meet," children are left alone at home at their own mercy- with a high risk of roaming the streets and subjected to "anti-social elements."

\section{Children as Domestic Workers}

Domestic child workers remain frequently seen in many cities and metropolitan areas. Organised exploitation becomes apparent. Children are made to serve as labourers by working for quite long hours, miserable food, wages, and in some cases, exposed to physical and sexual torment. There is a pressing need to enact required laws and amend existing ones towards addressing the challenges faced by such children.

\section{Street Child}

Street child or child who lives and works on the streets and highways remain a common occurrence in urban areas of many countries. They usually constitute horror and nuisance, which can hardly be ignored. Despite their large number on many streets within cities, there is little or no accurate information about them, especially regarding their actual numbers.

Furthermore, quite many deprived children also come in the form of child beggars, who, in one way or the other, face a high risk of indulging in little crimes, face the challenges of sexual and physical maltreatment. Another aspect is the "child sex workers" and child suffering from all forms of abuse. Such cases are found in all regions of the world. For example, in Africa, a high rate of sexual abuse has been recorded, especially during the covid-19 lockdown. In such cases, under-age children have been molested and abused. The issue occurs when adults or people of older age engage in sexual abuse, indecent exposing of children's genitals as well as forcefully viewing such genitals.

\section{Child Rights and Just Society for Sustainable Development}

The relevance of sustainable development and related issues requires continuous devotion and action all over the globe. In many instances, poverty issues, environmental degradation in the form of pollution or disturbing climate change, or other types of violence undermine the possibility of realizing peoples' needs, protecting fundamental human rights, and attaining full development possibilities (Arts, 2018). Formerly, the idea of sustainable development was believed to apply only to conditions in developing economies. However, this has changed radically since the embracing of the Sustainable Development Goals (SDGs) in 2015, which clearly expanded the idea of sustainable development to all nations (Moyer and Hedden 2020). Similarly, despite the global-wide coverage or endorsement of the Convention on the Rights of the Child, many children worldwide keep on being left behind and face denials of their rights, especially those who face discrimination. Such children include those who are living on the streets or under the migration situation. Additionally, children are affected by poverty challenges, violence, rising inequality and undue exclusion due to their level of sensitive state of life and development.

The 2030 Agenda that facilitates for acceptable Sustainable Development symbolizes the highest targets for a bright future for the children globally, of which the SDGs provide immense opportunities to clearly understand their rights in all member countries (UN 2019). Hence 
satisfying the children's rights by attending to all those left far behind is an essential precondition for accomplishing the 2030 Agenda in general. It is, therefore, crucial to devise an appropriate way of actualizing the SDGs such that children's rights and welfare are made a priority in all situations not only vital human rights but also strengthen sustainable development by creating a disconnect in the transmission path of poverty and marginalization from a certain generation to another. Thus, progress can be facilitated by placing children's rights among important priorities in action plans, especially within the sustainable development framework, significantly as child rights-centred patterns can increase future developmental gains.

It is clear that the present-day children and tomorrow remain vital to the sustainable development articulations and the prospects of this planet and its general inhabitants (UNICEF, 2013). However, it is a common practice that issues relating to the children and youth are merely regarded within the "social context." Other aspects concerning their health matters, educational requirements, safety and other basic rights are simply not considered. Others also include those inseparably connected to attaining economic growth and shared prosperity; while ensuring adequate natural eco-system protection alongside more stable, harmless and just societies.

Nonetheless, while various parts of the world show impressive progress, such is happening at a great cost. This includes an increase in the margin among the rich and poor individuals, the rising rate of toxic pollution and unplanned urbanization; extensive social effects of crisis occurrences and conflicts; excessive stress on the stimulating environment as well as persistent inaccessibility to important and "life-sustaining" food, clean water, unpolluted air and required security and well-being for the already high and in specific locations or countries rising population rate. Among those affected in such situations, the children are most likely to be highly vulnerable and exposed to dangerous situations. On this ground, the sustainable development efforts, protection of child rights and attaining a just society may likely be undermined.

\section{Barriers to establishing the child rights, justice and inclusion of deprived children}

The "UN Convention on the Rights of the Child" (1989) has changed the general views and manners we have towards children. It has taken steps in providing the principles necessary for protecting all kinds of vulnerable status of children and guarantee their placement as active and credible members of any society (Friðriksdóttir 2015). Furthermore, article 3's notion regarding the child's greatest interests is intended to warrant the attainment of both the full and adequate level in terms of enjoying all the recognised human rights in a conventional and holistic developmental path.

Obligations are mandated on member states to guarantee that all judicial and administrative resolutions alongside accepted policies and legislative provisions regarding the children are given the highest acceptable degree of primary consideration. At present, many countries show a high level of concern and efforts to establish the necessary rules for the provision of justice, the inclusion of deprived children, and curtail the rising cases of all other forms of child abuse. The concept or model designs of many countries have been encouraging and attractive in promoting child-friendly justice (Council of Europe, 2010; Guðbrandsson 2011). However, more efforts are required in the on-going process of consolidation and extending the integrated understanding and expertise on how the judicial system works. 
The "CRC Committee," having observed that their unique nature and dependent status, children face real problems and difficulties while trying to find solutions for with regards to breaches of their fundamental rights'. Some of these challenges and barriers can be viewed from a general perspective and they tend to affect children in an equal manner as they do to the adults:

Poverty and related economic status: This means a situation where affected individuals especially children, may find it difficult to afford a lawyer's services when the need arises, for example. Other relevant and general barriers may also include procedural costs required, location of affected courts, as well as physical accessibility, which all have effects on the child as well as adults in the process of accessing their rights as well as justice; others may include constitutional limitations and the prevention of legal standing (Shelton, 2015: 98-99; UN High Commissioner, 2013).

Children may face specific legal barriers, especially when they are denied certain standard capability, legal standing, or a required and competent lawyer to stand in their name. This can exceptionally be highly problematic in cases relating to conflict of interest amongst the child and his legitimate guardians or parents (Sahovic \& Eriamiatoe, 2019). Furthermore, children face certain barriers when trying to access justice regarding some particular challenges. Such barriers may be related to the complex nature of judicial systems, thereby creating unwanted difficulties for such children to have easy access and participate effectively. Hence, the need to adequately protect the child from any violence category remains a fundamental right as contained in the UNCRC. The inclusion of specifically target 16.2 (i.e., SDG 16.2) in the renowned "2030 Agenda for Sustainable Development" in order to put an end to all kinds of violence towards the children. Such an effort contributes immensely to the renewed drive towards the actualization of every child's rights to live in the absence of fear, disregard, abuse, and likely exploitation.

\section{Policy recommendations for a better situation}

This entry has made a clear conceptualisation of children's rights, especially as stipulated under the United Nations' universal human rights. Children's rights and how such rights have been violated were also discussed. Such violations of children's rights have in no little way to undermine the fundamental human rights and freedom of such children and tend to have a strong negative influence towards economic development. Similarly, children who go a little further towards having fair hearing and justice when necessary also find it difficult to attain such. Hence, to ensure the protection of children's rights, all the hurdles that deny easy access to justice by such children should be abolished. More attention and enforcement should also be provided towards implementing children's rights and access to justice in general and specific contexts.

Furthermore, great efforts must be put in place to overcome the existing challenges and support the actualization of inclusive and acceptably peaceful societies. Such measures should include additional effective and transparent protocols that are comprehensive and realistic within the government resources. Similarly, creating reliable and strongly independent institutions at national levels to protect human rights should be of significant priority. Lastly, steps are also required globally for the operationalization of births and deaths registration.

\section{Synonyms}


Child; Children's right; Justice; Deprived Children; Legal Framework; Eradication

\section{References}

Arts K.(2018) Children's Rights and the Sustainable Development Goals. in U. Kilkelly, T. Liefaard (eds.), International Human Rights of Children, https://doi.org/10.1007/978981-10-4184-6_18. Accessed 17 Nov 2020.

Campbell TD (1992). The rights of the minor: As person, as child, as juvenile, as future adult. International Journal of Law, Policy, and the Family. 6(1):1-23. https://academic.oup.com/lawfam/articleabstract/6/1/1/952675?redirectedFrom=fulltext. Accessed 31 October 2020.

Council of Europe (2010). Guidelines of the Committee of Ministers of the Council of Europe on child-friendly justice. Strasbourg: Council of Europe Publishing. https://rm.coe.int/16804b2cf3. Accessed on 30 Dee 2020.

Deb S, Modak S. (2010). Prevalence of violence against children in families in Tripura and its relationship with socio-economic factors. Journal of injury and violence research. (1):5. https://www.ncbi.nlm.nih.gov/pmc/articles/PMC3134897/ Accessed on 5 Nov. 2020.

Debowska A, Boduszek D, Sherretts N, Willmott D, Jones AD. (2018) Profiles and behavioral consequences of child abuse among adolescent girls and boys from Barbados and $\begin{array}{llll}\text { Grenada. } & \text { Child } & \text { abuse neglect. 245-58. }\end{array}$ https://doi.org/10.1016/j.chiabu.2018.02.018. Accessed on 30 Dee 2020.

Detrick, S. (1999). A commentary on the United Nations Convention on the Rights of the Child.

The Hague: Martinus Nijhoff Publishers. Accessed on 11 October 2020.

Ertan D, El-Hage W, Thierrée S, Javelot H, Hingray C. (2020). COVID-19: urgency for distancing from domestic violence. European journal of psycho-traumatology. 11(1):1800245.https://www.tandfonline.com/doi/full/10.1080/20008198.2020.1800245/ Accessed on 5 Nov. 2020.

Fromm S (2001). Total Estimates of Cost of Child Abuse and Neglect in the United States Statistical Evidence. Chicago Prevent Child Abuse America.

Geeta, C. (2015). Child Rights in India: Challenges and Social Action 1-23. https://www.researchgate.net/publication/303769823_Child_Rights_in_India_Challeng es_and_Social_Action. Accessed on 13 October 2020.

Guðbrandsson, Bragi. 2011. Towards a child-friendly justice and support for child victims of sexual abuse. In The Council of Europe Publication: Protecting children from sexual violence-A comprehensive approach, 85-96. Strasbourg: Council of Europe. Accessed on 30 Dee 2020.

Hillis S, Mercy J, Amobi A, Kress H. (2016). Global prevalence of past-year violence against children: a systematic review and minimum estimates. Pediatrics. 137(3). https://pediatrics.aappublications.org/content/137/3/e20154079/ . Accessed on 5 Nov 2020.

Hillis SD, Mercy JA, Saul JR.(2017). The enduring impact of violence against children. Psychology, Health \& Medicine. 22(4):393-405. https://www.tandfonline.com/doi/abs/10.1080/13548506.2016.1153679. Accessed on 7 Nov. 2020.

ICRW (International Center for Research on Women) (2007) New Insights on Preventing Child Marriage. A Global Analysis of Factors and Programs. Washington, DC: USAID, ICRW, PACT, and IGWG. 
International Labour Organization (2017). Global estimates of child labour: Results and trends, 2012-2016. https://www.ilo.org/wcmsp5/groups/public/---dgreports/--dcomm/documents/publication/wcms_575499.pdf Accessed on 7 Nov. 2020.

Lee, BX., Kjaerulf, F., Turner, S., Cohen, L., Donnelly, PD., Muggah, R., ... Gilligan, J. (2016). Transforming our world: Implementing the 2030 Agenda through Sustainable Development Goal indicators. Journal of Public Health Policy, 37(1), S13-S31. https://doi.org/10.1057/s41271-016-0002-7. Accessed $1^{\text {st }}$ Nov. 2020.

Miles S, Singal N (2010). The Education for All and inclusive education debate: conflict, contradiction or opportunity? International journal of inclusive education. 14(1):1-5 doi:10.1080/13603110802265125. Accessed on 4 Nov 2020.

Moyer JD, Hedden S. (2020) Are we on the right path to achieve sustainable development goals?. World Development. 127:104749. https://www.sciencedirect.com/science/article/pii/S0305750X19303985. Accessed on 17 Nov 2020.

National Commission of Inquiry into the Prevention of Child Abuse (1996). Childhood Matters: The Report of the National Commission of Inquiry into the Prevention of Child Abuse, Vol. 1. London, Her Majesty's Stationary Office. Cited in: Runyan D et al. (2002). Child Abuse and Neglect by Parents and Other Caregivers. In: Krug EG et al. (Eds). World Report on Violence and Health. Geneva, World Health Organization, pp 59-86.

Pinheiro PS (2006) World Report on Violence Against Children. New York: UN.

Plan International (2006) Suffering to Succeed? Violence and Abuse in Schools in Togo. Woking: Plan International.

Quennerstedt A, Robinson C, I'Anson J (2018). The UNCRC: The voice of global consensus on children's rights?. Nordic Journal of Human Rights.36(1):38-54. https://www.tandfonline.com/doi: 10.1080/18918131.2018.1453589. Accessed on 5 Nov. 2020.

Sahovic, N. V., \& Eriamiatoe, P. (2019). Effectiveness of the Convention on the Rights of the Child in realisation of the right to a remedy for Child victims of violence in Africa. Child Abuse \& Neglect, 104307. Accessed on 16/10/2020. From: https://www.sciencedirect.com/science/article/abs/pii/S0145213419304831.

Sandel MJ (2009). Justice: What's the Right Thing to Do? https://images.macmillan.com/folioassets/discusion-guides/9780374180652DG.pdf Accessed: 1 Nov 2020.

Senante AE, Bellio F, Curet F, Gaspari M (2018). The violation of the Rights of the Child and the International Protection. Available at: https://resourcecentre.savethechildren.net/node/3453/pdf/3453.pdf.

Sever L, Balat A. (2020). Renal crisis in children during armed conflict. In Seminars in Nephrology (Vol. 40, No. 4, pp. 408-420). WB Saunders. https://www.sciencedirect.com/science/article/abs/pii/S0270929520300784 Accessed on 5 Nov. 2020.

Shelton, D. (2015), Remedies in international human rights law (Oxford: Oxford University Press). doi:10.1093/acprof:oso/9780199207534.001.0001.

Shenoda S, Kadir A, Pitterman S, Goldhagen J (2018). The effects of armed conflict on children.

Pediatrics.

142(6). https://pediatrics.aappublications.org/content/142/6/e20182585. Accessed 5 Nov. 2020.

Temin M, Levine R (2010) Start with a Girl. A New Agenda for Global Health. Washington, DC: CGD.

United Nations Human Rights (2019) Children's Rights and the 2030 Agenda for Sustainable Development. https://ohchr.org/EN/Issues/Children-OHCHR/Pages/2030SDA.aspx. Accessed 17 Nov 2020. 
UNICEF (2006) Commercial Sexual Exploitation. Child Protection INFORMATION Sheet. $\begin{array}{lllll}\text { Accessed } & \text { on } & 30 & \text { Dee } & 2020\end{array}$ https://www.unicef.org/chinese/protection/files/Sexual_Exploitation.pdf

UNICEF (UN Children's Fund) (2010) At Home or in a Home? Formal Care and Adoption of Children in Eastern Europe and Central Asia. Geneva: UNICEF Regional Office for CEE and CIS.

UNICEF, (2013) Sustainable development starts and ends with safe, healthy and well-educated children.

https://sustainabledevelopment.un.org/content/documents/3372SD_children_FINAL.pd f. It was accessed 17 Nov 2020.

UNICEF (2020a). Child marriage around the world. https://www.unicef.org/stories/childmarriage-around-world. Accessed on 5 Nov. 2020.

UNICEF (2020b) Violence against children. Available at: https://www.unicef.org/protection/violence-against-children (accessed on 24 September 2020).

UNICEF (2020c). The Legal Framework for Child Protection in South Asia https://www.unicef.org/rosa/media/5906/file/The_legal_framework_for_child_protectio n_in_south_asia.pdf.

USAID (US Agency for International Development) (2003) Unsafe Schools: A Literature Review of School-related Gender-based Violence in Developing Countries. Washington, DC: USAID.

WHO (World Health Organization) and ISPCAN (International Society for the Prevention of Child Abuse and Neglect) (2006) Preventing Child Maltreatment. A Guide to Taking Action and Generating Evidence. Geneva: WHO.

United Nations (1989) The Convention on the Rights of the Child, reprinted in Children, Rights and the Law, P. Alston, S. Parker and J. Seymour (eds.), Oxford: Oxford University Press: 245-264; and in L. LeBlanc, The Convention on the Rights of the Child. United Nations Lawmaking on Human Rights, Lincoln: University of Nebraska Press 293-316. https://www.ohchr.org/Documents/ProfessionalInterest/crc.pdf. Accessed on 10 October 2020.

United Nations (2018) Millions of children in crisis zones face 'bleak future, ' UNICEF warns, launching emergency appeal. United Nations News. https://news.un.org/en/story/2018/01/1001531. Accessed on 4 Nov 2020.

United Nations (2020) Child Marriages: 39,000 Every Day - More than 140 million girls will marry between 2011 and 2020. Accessed on 30 Dee 2020, from: https://www.un.org/youthenvoy/2013/09/child-marriages-39000-every-day-more-than140-million-girls-will-marry-between-2011-and-2020/. 